\title{
IMPACT OF AGE AND BODY MASS INDEX ON THE BIOELECTRICAL PROPERTIES OF BREAST TISSUE: IN-VIVO STUDY
}

\author{
Islam G. Ali \\ Department of Medical Biophysics \\ Medical Research Institute, \\ Alexandria University, Alexandria, Egypt
}

\begin{abstract}
Biological tissues have complex electrical impedance identified with the tissue volume, the internal structure, the arrangement of the constituent cells and the physiologic status. Since the breast's contents vary with age, breast tissues have various conductivities and permittivities. Based on the results of this study, the effect of both age and BMI on the electrical conductivity of the breast tissue at $10 \mathrm{kHz}$ is within $5 \%$, while the effect on breast relative permittivity is within $10 \%$ even in an extreme case.
\end{abstract}

Keywords-Bioelectrical Properties, Breast electrical conductivity, Breast electrical permittivity, BMI

\section{INTRODUCTION}

The electrical conductance of biological tissue is determined by its constituents. Tissue consists of extracellular fluid and cells containing the intracellular fluid inside the cell membrane. The extracellular fluid is the medium surrounding the cells, also denominated the extracellular space [1]. It contains proteins and electrolytes including the plasma and the interstitial fluid. The cell is constituted by a lipid bi-layer plasma membrane containing the protoplasm that contains the cytosol, the organelles and the nucleus of the cell [2].

In metals the electrical charge carriers are electrons, but in electrolytes the charge carriers are ions - ("cations" if their charge is positive, and "anions" if the charge is negative). An electrolyte is able to conduct electric current in the presence of an external electrical field [3]. Both intracellular and extracellular fluids are electrolytes because they contain ions, which are free to migrate and transport the electrical charge. Therefore, we can consider biological tissue electrically and macroscopically an ionic conductor. The total ionic conductivity of a solution depends on the concentration, activity, charge and mobility of all free ions in the solution. The most important ions contributing to the ionic current in living tissue are $\mathrm{K}^{+}, \mathrm{Na}^{+}$and $\mathrm{Ca}^{2+}$, with approximate intracellular concentration $100 \mathrm{mM}, 10-20 \mathrm{mM}$, and $10^{-4} \mathrm{mM}$ respectively, while the approximate extracellular concentration $5 \mathrm{mM}, 150$
$\mathrm{mM}$ and $1 \mathrm{mM}$ respectively. and It should be noted that all three of these are cations [4].

Any material with the ability to store capacitive energy can be classified as a dielectric, and living tissue has this ability due to its constituents at any level, molecular, subcellular, or cellular. The compositions of the extracellular and intracellular fluids, especially the organelles, contribute to the overall behavior of tissue as a dielectric, but the plasma membrane is the cellular structure with the major contribution to the dielectric behavior of living tissue. The dielectric properties are also influenced by the specific tissue structure $[5,6]$.

The female breast tissue consists of average of 33\% mammary gland and $66 \%$ adipose tissue (overall $31 \%$ water and $57 \%$ lipids) [7]. The fat is most abundant in the outermost layer. Below this layer, there are many mammary glands surrounded by a mesh of dense fibrous connective tissue and fat. Each mammary gland is filled with about twenty lobules. Inside the lobules, alveolar milk-secreting cells coalescence to form intralobular ducts lined with epithelial and myoepithelial cells. The intralobular ducts (surrounded by loose connective tissue) combine and a single lactiferous duct exits each lobule. These ducts converge in the central, front portion of the breast, and they dilate creating lactiferous sinuses. Finally, the ducts empty out 15-25 $0.5 \mathrm{~mm}$ wide openings in the nipple. The entire breast has a rich blood supply and lymphatic system. The breast's contents vary with age and physiologic status (i.e. estrogen, progesterone levels). After menopause, the mammary glands decrease in size and the secretory portions atrophy leaving a greater proportion of fat tissue. The interlobular connective tissue also atrophies [8].

The dielectric properties of breast tissue, especially its electrical conductivity (denoted as $\sigma$ in units of Siemens/meter $(\mathrm{S} / \mathrm{m})$ ), have long been investigated in vitro and in vivo using electrical bioimpedance tomography (EBT) systems [9]. Findings have consistently shown that malignant breast cancers present elevated conductivity values when compared to normal tissue. The conductivities of malignant mammary samples are typically in the range of $0.8 \sim 1.4 \mathrm{~S} / \mathrm{m}$, while those 


\section{International Journal of Engineering Applied Sciences and Technology, 2020 \\ Vol. 4, Issue 10, ISSN No. 2455-2143, Pages 5-8 \\ Published Online February 2020 in IJEAST (http://www.ijeast.com)}

of normal tissue are between $0.1 \sim 0.2 \mathrm{~S} / \mathrm{m}$ at a frequency of $\sim 100 \mathrm{MHz}[10,11]$. The biological mechanism behind the elevated conductivity is attributed to factors such as the presence of necrosis and cell membranes breakdown, increased cell membrane charge, sodium concentration, and water content. [12].

As mentioned earlier the breast's contents vary with age, in a study done by Zain et al. (2014) [13] showed that there are some factors which effect on mean electrical conductivity of EIT for the breast tissue, and found that the mean electrical conductivity value of Malaysian women were increased with age, but this value is lower than the standard Caucasians $(\mathrm{p}<0.05)$. Also, their study showed there was strong positive correlation between ranked BMI and mean electrical conductivity value $(\mathrm{p}=0.001)$. The aim of this study is to investigate the influence of age variation and Body Mass Index (BMI) on the breast tissue electrical conductivity and relative permittivity with an electrical pulses $0.4 \mathrm{~mA}$ at frequency 10 $\mathrm{kHz}$.

\section{EXPERIMENTAL METHOD}

In this study a total of 52 volunteered healthy women divided into two groups; first group consists of 26 women selected to be had approximately $\mathrm{BMI}=(25 \pm 0.4) \mathrm{Kg} / \mathrm{m}^{2}$ at different ages (35-61) years old, and the second group consists of 26 women selected to be at approximately age $(40 \pm 0.5)$ years old with different $\mathrm{BMI}=(18.2-36.1) \mathrm{Kg} / \mathrm{m}^{2}$. All volunteers were examined using Electrical Bioimpedance Tomography (EBT) system at Department of Radiology, Medical Research Institute, Alexandria University, Egypt. after all the volunteers completed the necessary consent forms.

\section{A. EBT System Overview -}

This device consists of an array of 64 stainless steel electrodes $(8 \times 8)$ array with $10 \mathrm{~mm}$ diameter spaced by $5 \mathrm{~mm}$ fabricated on a printed circuit board and embedded in a Plexiglas plate. These electrodes array connected to the main unit which consists of multi frequency alternating current (AC) voltage source, Microcontroller, Multiplexers, Analog to Digital Converter (ADC), divider circuit, peak detector system, and computer for running software, A schematic diagram for EBT system is shown in Figure [1].

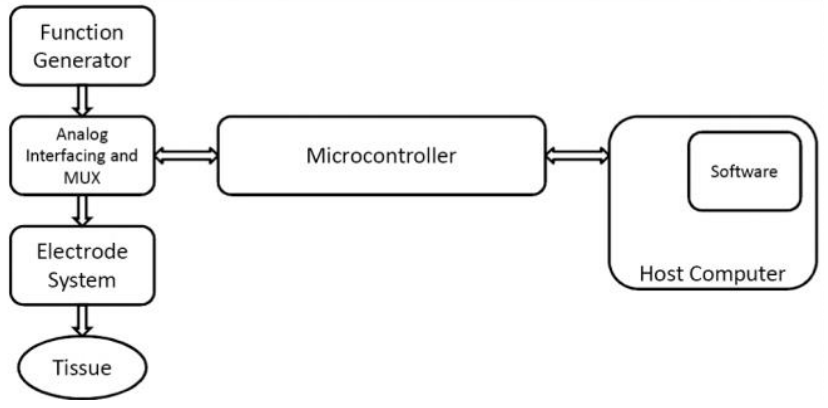

Fig. 1. A schematic diagram for EBT system hardware.

\section{B. Breast Tissue Measurements-}

Using small electrical pulses $(0.4 \mathrm{~mA}, 10 \mathrm{kHz})$ applied to breast tissue through the electrodes for all cases as shown in Figure [2]. The procedure continues for each electrode, measurements are taken within 30 seconds. The data collected from all contacted electrodes with breast peripheries and mean electrical conductivity and relative permittivity are calculated and plotted versus age and BMI.

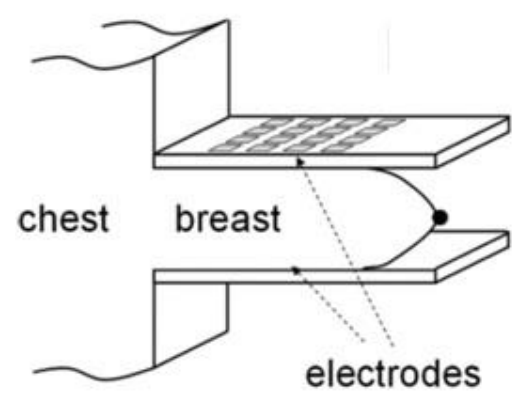

Fig. 2. A schematic diagram depicts the applocation of electrodes to breast tissues.

\section{RESUlt AND DisCUSSION}

In order to investigate the effect of age on the electrical conductivity and permittivity of the breast tissue the graphs have been plotted to study the correlations and its significance. Measurements of the first group depicted in Figure [3] that shows A linear fitting for the correlation between breast conductivity and age was found to be $y=0.001 x+0.2015$, where the slope is $0.001\left(\mathrm{~S} / \mathrm{m}^{*}\right.$ year) and the $\mathrm{R}^{2}=0.0074$. The error in the slope calculation was estimated using the least square fit theory, $\pm 0.82 \times 10^{-4}$ ( $\mathrm{S} / \mathrm{m}^{*}$ year), there is a very weak correlation of breast tissue electrical conductivity with age at 10 $\mathrm{kHz}$.

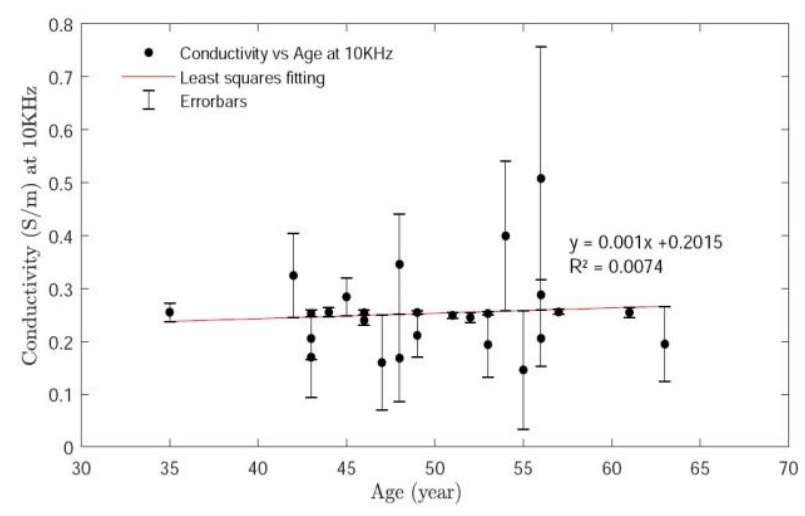

Fig. 3. The relation between electrical conductivity of the breast tissue and age at $10 \mathrm{kHz}$.

While The correlation of breast tissue relative permittivity as a function of age at frequency $10 \mathrm{kHz}$ shown in Figure [4], The linear fitting for this relation was found to be $y=1022.8 x+$ 74526, where the slope is $1022.8\left(\right.$ year $\left.^{-1}\right)$ and the $\mathrm{R}^{2}=0.0808$. 


\section{International Journal of Engineering Applied Sciences and Technology, 2020 \\ Vol. 4, Issue 10, ISSN No. 2455-2143, Pages 5-8 \\ Published Online February 2020 in IJEAST (http://www.ijeast.com)}

The error in the slope calculation was estimated using the least square fit theory. The error bars are shown in the graph as well. The error estimate for the value of the slope was found, \pm 4.016 (year $^{-1}$ ). There is a poor positive relation with slightly increase in relative permittivity with age with no significance.

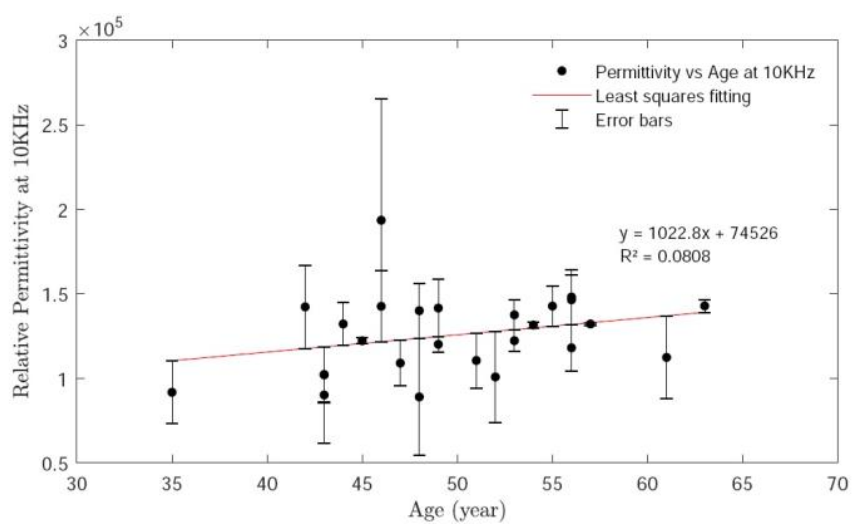

Fig. 4. The relation between relative permittivity of the breast tissue and age at $10 \mathrm{kHz}$.

In the second group, the investigation of the impact of BMI on electrical conductivity and relative permittivity of breast tissue has been studied similarly. Figure [5], illustrate the relation of breast conductivity as a function of BMI at frequency $10 \mathrm{kHz}$, the linear fitting for this relation was found to be $y=$ $0.0034 x+0.1672$, where the slope is $0.0034\left(\mathrm{~S}^{*} \mathrm{~m} / \mathrm{Kg}\right)$ and the $\mathrm{R}^{2}=0.0293$. The error estimate for the value of the slope was found using the least square fit theory, $\pm 1.4 \times 10-4\left(\mathrm{~S}^{*} \mathrm{~m} / \mathrm{Kg}\right)$.

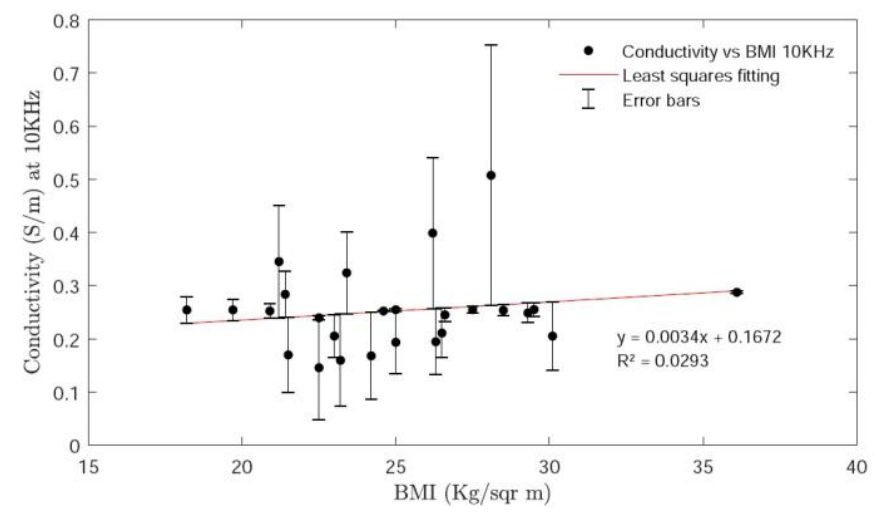

Fig. 5. The relation between breast tissue conductivity and BMI at $10 \mathrm{kHz}$.

While in Figure [6], the linear fitting for the relation of breast relative permittivity with BMI was found to be $y=2192.3 x+$ 70579 , where the slope is $2192.327\left(\mathrm{~m}^{2 /} \mathrm{Kg}\right)$ and the $\mathrm{R}^{2}=$ 0.1326 . The error estimate for the value of the slope was found using the least square fit theory, $\pm 0.1326\left(\mathrm{~m}^{2} / \mathrm{Kg}\right)$.

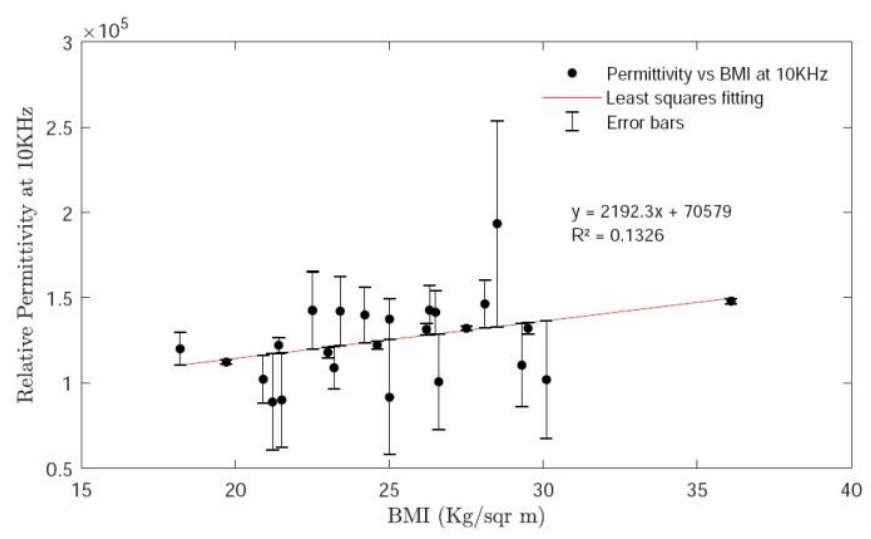

Fig. 6. The relation between relative permittivity of the breast tissue and BMI at $10 \mathrm{kHz}$.

The study showed there was a slightly positive correlation between ranked BMI and mean breast permittivity values.

\section{CONCLUSION}

In conclusion, based on the results of this study, the effect of both age and BMI on the electrical conductivity of the breast tissue at $10 \mathrm{kHz}$ is within $5 \%$, while the effect on breast relative permittivity is within $10 \%$ even in an extreme case. With EBT measurements, there two most important factors that affect EBT sensitivity, careful electrode plate positioning and the patient's remaining motionless during measuring procedure.

\section{REFERENCES}

[1] Grimnes, S., and Martinsen, O.G., (2000), Electrical Properties of Tissue, Bioimpedance \& Bioelectricity Basics', Academic Press, ISBN-0-12-303260., (pp. 87125)

[2] Guyton, A. C., and Hall, J. E., (2006), Transport of Substances Through the Cell Membrane Texbook of Medical Physiology (11th ed.), Philadelphia: W.B.Saunders Company, ISBN 0-7216-0240-1, (pp. 4555).

[3] Earl, D., and Gates, (2007), Introduction to Electronics, 5th edition, chapter 16, (pp155-160).

[4] Julian, L., Seifter, and Hsin-Yun, Chang, (2017), Extracellular Acid-Base Balance and Ion Transport Between Body Fluid Compartments. Int. Union Physiol. Sci./Am. Physiol. Soc. Volume 32, Issue 5, (pp. 367-379)

[5] Suroviec, A J, Stuchly, S S, Barr, J R and Swarup, A. (1988), Dielectric properties of breast carcinoma and the surrounding tissues IEEE Trans. Biomed. Eng. 35, (pp. 257-263).

[6] Asami, K, Takahashi, Y, and Takashima, S., (1989), Dielectric properties of mouse lymphocytes and 


\section{International Journal of Engineering Applied Sciences and Technology, 2020 \\ Vol. 4, Issue 10, ISSN No. 2455-2143, Pages 5-8 \\ Published Online February 2020 in IJEAST (http://www.ijeast.com)}

erythrocytes. Biochimica et Biophysica Acta. 1010, (pp. 49-55).

[7] Twelves, D et al., (2012), The anatomy of fluid-yielding ducts in breast cancer. Breast Cancer Res Treat. 132(2): (pp. 555-564).

[8] Junqueira, LC, J. Carneiro, and R. Kelley. (1995), Basic Histology. 8th edition, A ppleton \& Lange, (pp. 443-446).

[9] Sha, L, Ward, ER, and Story, B., (2002), A review of dielectric properties of normal and malignant breast tissue. In: Proc IEEE SoutheastCon. (pp 457-461).

[10] Joines, WT, Zhang, Y, Li, C, and Jirtle, RL. (1994), The measured electrical properties of normal and malignant human tissues from 50 to $900 \mathrm{MHz}$. Med Phys. 21: (pp. 547-550).

[11] Surowiec, AJ, Stuchly, SS, Barr, JB, and Swarup, A., (1988), Dielectric properties of breast carcinoma and the surrounding tissues. IEEE Trans Biomed Eng. 35: (pp. 257-263).

[12] Chaudhary, SS, Mishra, RK, Swarup, A, and Thomas, JM., (1984), Dielectric properties of normal \& malignant human breast tissues at radiowave \& microwave frequencies. Indian Biochem Biophys. 21: (pp. 76-79).

[13] Zain, NM, and Chelliah, KK (2014a), Breast imaging using electrical impedance tomography: correlation of quantitative assessment with visual interpretation. Asian Pac J Cancer Prev, 15, (pp. 1327-1331). 